\title{
Increased Plasma Renin Activity in Juvenile Essential Hypertension
}

\author{
Katsuhiko Nakamura MD and Kiyofumi Hirata MD
}

\begin{abstract}
Plasma renin activity (PRA) was determined in 20 normal young adult controls, in 50 young patients with essential hypertension, and in 96 older patients with essential hypertension. The results obtained showed that PRA was significantly increased over the first five years following the onset of hypertension in young hypertensive patients who had a family history of hypertension. In contrast, in the older hypertensive patients PRA was significantly decreased when compared to normal controls and young hypertensive patients. These data may indicate that the renin-angiotensin system is enhanced during the developmental stages of human essential hypertension and suppressed afterwards.
\end{abstract}

Key Words: Plasma renin activity (PRA), Juvenile essential hypertension, Family history of hypertension, Age-distribution, Renin-angiotensin system, Pathogenesis of essential hypertension.

It has been well known that renin secretion and plasma renin activity (PRA) may be high, normal or low in patients with essential hypertension ${ }^{1-5}$. Consequently the role of the renin-angiotensin system in the pathogenesis of human essential hypertension remains unclear. However, it has been also shown that in spontaneously hypertensive rats (SHR), a typical model of essential hypertension, PRA and kidney renin activity (KRA) both increase in the early stages of the initiation of hypertension ${ }^{6)-9}$. The purpose of the present study was to determine whether an increased PRA (hyperreninemia) could be detected in a sizable population of the patients with so-called juvenile essential hypertension. The results indicate that hyperreninemia does occur very soon after the development of hypertension particularly among the young people who have family history of hypertension.

\section{MATERIALS AND METHODS}

Normotensive controls

Twenty normal young adults were selected out of our medical staffs and students. None had a prior history of hypertension and all were free from symptoms of cardiovascular, renal or metabolic disease. They consisted of 14 men and 6 women, aged from 22 to 36 years with mean of 29.5.

Patients with essential hypertension

One hundred forty-six patients had been diagnosed as having no underlying cause of their elevated blood-pressures. Diagnostic criteria were as follows. Systolic blood pressure $\geqq 150 \mathrm{mmHg}$ or diastolic blood pressure $\geqq 90 \mathrm{mmHg}$, or both. Neither positive finding in urinalysis and urine vanillymandelic acid nor abnormalities in serum electrolytes, renal function and intravenous pyelography. When diagnosis was difficult

From the Second Department of Internal Medicine, Toho University School of Medicine, Tokyo.

Received for publication April 20, 1978.

Reprint request to: Dr Katsuhiko Nakamura, The Second Department of Internal Medicine, Toho University School of Medicine, 11-1, 6-chome Ohmori-Nishi, Ohta-ku Tokyo, 143, Japan. 
to make, renal angiography or biopsy was performed to exclude the possibilities of renovascular hypertension and renal parenchymal disease.

Classification of hypertensive patients

Patients with essential hypertension were divided into two groups depending on age-distribution. When their age was less than forty or more, they were defined as young or older patients with essential hypertension. Young hypertensive patients were classified according to their family history of hypertension, duration of hypertension ( $\mathrm{Yr}$ ), degree of hypertension (WHO classification), electrocardiogram (ECG), cardio-thoracic ratio (GTR) on chest x-ray and eyeground (KW) findings (Table 2).

Young patients with essential hypertension

Fifty young hypertensive patients met the above diagnostic criteria. Most individuals were employee of business organizations or students of public schools where health-examinations including urinalysis and blood-pressure determinations were carried out at least once or twice every year. They consisted of 43 men and 7 women, aged from 15 to 39 years with mean of 29.2.

Older patients with essential hypertension

Ninety-six older patients with essential hypertension were all ambulatory and none received any antihypertensive drug or diuretic prior to PRA determination. They consisted of 36 men and 60 women, aged from 40 to 80 years with mean of 56. 4 .

Renin assay

An early morning blood sample for assay of PRA was withdrawn with the patient supine and at rest. Immediately afterwards a dose of $40 \mathrm{mg}$ of furosemide was injected intravenously and subjects were asked to stand or walk for a 2 hour period. At the end of this period, blood was obtained for the "stimulated" PRA determination. PRA was determined by the radioimmunoassay method of Dinabot Renin-Riakit ${ }^{10)}$.

Statistics

Changes in PRA were assessed using Student's paired t-test. All other comparisons between groups were made using Student's unpaired t-test.

\section{RESULTS}

Data of PRA from all the groups of subjects studied are shown with mean and standard deviation (SD) in Table 1. PRA was consistently increased $(p<0.001)$ after postural and diuretic stimuli in each group of subjects.

In comparing normal controls to all young patients with essential hypertension the average resting PRA was found to be higher in hypertensive patients than in normal controls, but the difference between the means was statistically insignificant $(t=1.93,0.05<p<0.1)$. In contrast, the average stimulated PRA was significantly higher $(t=2.63, p<0.02)$ in the total population of young essential hypertensive patients.

The older groups of patients with essential hypertension were found to have significantly lower PRA, both resting and stimulated $(t=3.74, p<0.005 ; t=4.98, p<$ 0.001 ), than the normal group of controls.

Table 1. PRA (mean \pm SD) in normal controls and patients with essential hypertension

\begin{tabular}{|c|c|c|c|c|c|}
\hline Subjects & $\begin{array}{c}\text { Age } / \text { yr } \\
\text { mean (range) }\end{array}$ & $\begin{array}{l}\text { No.of } \\
\text { cases }\end{array}$ & $\begin{array}{l}\text { PRA (ng/ } \\
\text { resting }\end{array}$ & $\begin{array}{l}\text { 1/hr) } \\
\text { stimulated }\end{array}$ & Difference \\
\hline Normal controls & $\begin{array}{c}29.5 \\
(22 \sim 36)\end{array}$ & 20 & $1.42 \pm 0.71$ & $2.66 \pm 1.03$ & $p<0.001$ \\
\hline Patients with & $\begin{array}{c}29.2 \\
(15 \sim 39)\end{array}$ & 50 & $1.97 \pm 1.27$ & $3.87 \pm 2.04$ & $p<0.001$ \\
\hline essential hypertension & $\begin{array}{c}56.4 \\
(40 \sim 80)\end{array}$ & 96 & $0.86 \pm 0.67$ & $1.42 \pm 1.03$ & $\mathrm{p}<0.001$ \\
\hline
\end{tabular}


Table 2. PRA (mean $\pm \mathrm{SD}$ ) in subgroups of young patients with essential hypertension.

\begin{tabular}{|c|c|c|c|c|}
\hline \multicolumn{2}{|c|}{ Subgroups } & \multirow{2}{*}{$\begin{array}{c}\begin{array}{l}\text { No. of } \\
\text { cases }\end{array} \\
17 \\
18 \\
15\end{array}$} & \multicolumn{2}{|c|}{ 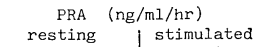 } \\
\hline $\begin{array}{l}\text { Family history } \\
\text { of hypertension }\end{array}$ & $\begin{array}{l}\text { Present } \\
\text { Absent } \\
\text { Unknown }\end{array}$ & & $\begin{array}{l}2.84 \pm 1.53 \\
1.59 \pm 0.90 \\
1.39 \pm 0.86\end{array}$ & $\begin{array}{l}4.06 \pm 2.25 \\
3.98 \pm 2.02 \\
3.62 \pm 2.12\end{array}$ \\
\hline $\begin{array}{l}\text { Duration of } \\
\text { hypertension }(\mathrm{yr})\end{array}$ & $\begin{array}{rr}\text { A } & 1 \\
\text { B } & 1 \sim 5 \\
\text { C } & 5 \sim 10 \\
\text { D } & >10\end{array}$ & $\begin{array}{r}24 \\
18 \\
4 \\
4\end{array}$ & $\begin{array}{l}2.12 \pm 1.12 \\
2.11 \pm 1.61 \\
1.41 \pm 1.16 \\
1.68 \pm 1.34\end{array}$ & $\begin{array}{l}4.73 \pm 2.03 \\
3.56 \pm 1.79 \\
2.73 \pm 1.93 \\
2.20 \pm 1.29\end{array}$ \\
\hline $\begin{array}{l}\text { Degree of } \\
\text { hypertension (wHO) }\end{array}$ & $\begin{array}{l}\text { I } \\
\text { II } \\
\text { III }\end{array}$ & $\begin{array}{r}10 \\
32 \\
8\end{array}$ & $\begin{array}{l}2.17 \pm 1.83 \\
1.95 \pm 1.28 \\
1.84 \pm 1.08\end{array}$ & $\begin{array}{l}4.47 \pm 2.45 \\
3.62 \pm 2.01 \\
3.48 \pm 1.87\end{array}$ \\
\hline $\mathrm{EC} \mathrm{G}$ & $\begin{array}{l}\text { Normal } \\
\text { Abnormal }\end{array}$ & $\begin{array}{l}28 \\
22\end{array}$ & $\begin{array}{l}1.78 \pm 0.85 \\
2.21 \pm 1.66\end{array}$ & $\begin{array}{l}3.69 \pm 1.66 \\
4.90 \pm 2.47\end{array}$ \\
\hline Chest X-ray (CTR) & $\begin{array}{l}<50 \% \\
>50 \%\end{array}$ & $\begin{array}{r}47 \\
3\end{array}$ & $\begin{array}{l}2.01 \pm 1.29 \\
1.29 \pm 0.83\end{array}$ & $\begin{array}{l}4.00 \pm 2.03 \\
1.87 \pm 1.00\end{array}$ \\
\hline Eye-ground (KW) & $\begin{array}{l}0 \\
\text { I } \\
\text { II }\end{array}$ & $\begin{array}{r}28 \\
16 \\
6\end{array}$ & $\begin{array}{l}1.65 \pm 0.91 \\
2.51 \pm 1.68 \\
1.99 \pm 1.17\end{array}$ & $\begin{array}{l}3.74 \pm 1.89 \\
4.73 \pm 2.18 \\
2.15 \pm 1.12\end{array}$ \\
\hline
\end{tabular}

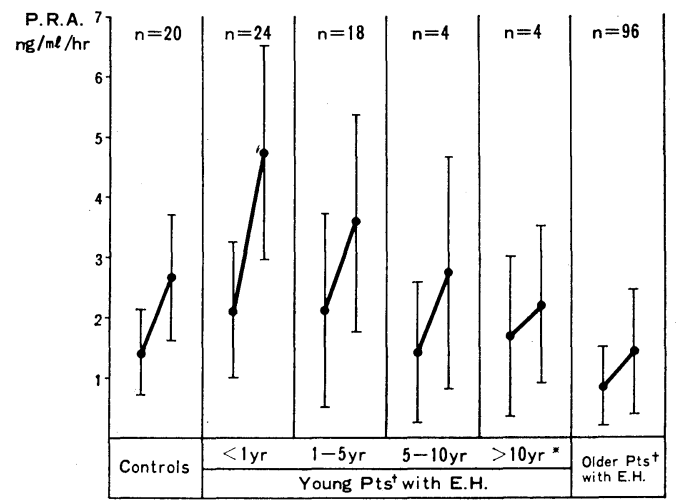

Fig. 1. Comparison of PRA between normal controls and young or older patients with essential hypertension (E.H.) Each panel shows the mean and SD (vertical line) of resting PRA (left) and stimulated PRA (right). (*) denotes duration of hypertension in young patients with E. H.

Since increased PRA was noted in patients with juvenile essential hypertension, further analysis was performed to see what factor or factors might be responsible for such an elevated PRA. Tab. 2 and Fig. 1 summarize PRA of six subgroups based upon noted clinical features of the young essential hypertensive patients.

In 17 patients with a family history of hypertension resting PRA $(2.84 \pm 1.53 \mathrm{ng} /$ $\mathrm{ml} / \mathrm{hr})$ was significantly higher $(\mathrm{p}<0.01)$ than the 18 patients with no family history of hypertension and 15 patients with unknown family history.

Duration of hypertension was found to be closely correlated to observed levels of PRA. In group A, PRA of 24 patients with hypertension of less than one year's duration averaged $2.12 \pm 1.12 \mathrm{ng} / \mathrm{ml} / \mathrm{hr}$ resting and $4.73 \pm 2.03 \mathrm{ng} / \mathrm{ml} / \mathrm{hr}$ stimulated. These figures were significantly higher $(\mathrm{t}=2.43, \mathrm{p}<0.02 ; \mathrm{t}=4.09, \mathrm{p}<0.001)$ when compared to the respective values of normal controls $(1.42 \pm 0.71 \mathrm{ng} / \mathrm{ml} / \mathrm{hr}$ and $2.66 \pm 1.03 \mathrm{ng} / \mathrm{ml} / \mathrm{hr}$ ). In group $\mathrm{B}$, the average PRA of 18 patients with hypertension of 1-5 years' duration was still significantly higher $(p<0.05)$ than those of the controls. In the $\mathrm{C}$ and $\mathrm{D}$ groups, PRA of 8 patients with hypertension of more than 5 years' duration was not significantly different from the controls.

There were no significant correlations observed between PRA and the other clinical features which were examined except for the group in which hypertensive changes were seen in the eye-ground. Resting PRA was higher $(\mathrm{p}<0.05)$ in 16 patients with KW-I retinopathy than in 28 patients without retinopathy, while stimulated PRA was lower $(p<0.05)$ in 6 patients with KW-II retinopathy than in patients without or with KW-I retinopathy.

\section{DISCUSSION}

This study was conducted primarily to determine the levels of PRA at rest and after stimuli, especially during the developmental stages of young essential hypertensive patients. The results indicate that hyperreninemia does exist commonly in about 50 per cent of the observed patients with juvenile essential hypertension. Furthermore, elevations of PRA occur in the very early stages of hypertension especially among the people who have family history of hypertension.

The results of this study show remarkable similarity to the observed changes in PRA which have been reported in the 
Okamoto strain of SHR (11). Specifically in the SHR both KRA and PRA increase progressively during the prehypertensive phase and remain at the high levels during the initial phase of hypertension, returning to normal or subnormal during the established phase of hypertension ${ }^{6)-9}$.

Elser and his co-workers ${ }^{12) 13)}$ recently reported that hyperreninemia wasfound in some cases of mild or borderline essential hypertension and suggested that the hypertension in these patients with high renin activitywas of neurogenic origin. Whether the raised renin activity is due to the sympathetic overactivity or vice versa remains to be clarified, since an increase in plasma noradrenaline concentration ${ }^{13) 14}$ has been often found in young patients with essential hypertension. It is possible that the juxtaglomerular ( $\mathrm{JG}$ ) cells respond with increased renin activity to either functional or morphological narrowing processes at the level of renal arterioles in SHR and hypertensive patients, since the renin status in experimental nephrosclerosis (15) appears quite similar to that in SHR. It has been suggested that the suppression of increased PRA observed in both SHR and in older patients with essential hypertension could be due to a stretch induced reaction of the JG cells against sustained high blood pressures ${ }^{916) 17}$.

The present study clearly demonstrates that the renin profile in essential hypertension varie with age-distribution and duration of hypertension. Although this study was mainly directed to the determination of PRA, it appears clear that the rises in PRA noted in young hypertensive patients increase the rate of angiotensin generation in the body and this in turn results in cardiovascular stimulation. Whether activated angiotensin might affect directly or indirectly on the cardiovascular system is not known, since hypotensive response to angiotensin II analogue in benign essential hypertension (18) has been claimed through the sympathetic nervous system.
According to the recent reviews by Gordon $^{19)}$ and Tobian ${ }^{20)}$, the possibility of the renal basis of essential hypertension has been suggested rather than ruled out, either morphologically or functionally as well as genetically. Therefore, it is reasonably assumed that our data may suggest the renal mechanism through which renin releases is enhanced during the developmental stages of essential hypertension and suppressed thereafter.

ACKNOWLEDGEMENTS: We wish to acknowledge the excellent technical advice of $\mathrm{Dr}$ Takao Saruta, Instructor of the Department of Medicine, Keio University School of Medicine for renin assay. This work was supported by grants from the Adult Disease Foundation.

\section{REFERENCES}

1) Kaneko $Y$, Ikeda $T$, Takeda $T$, et al: Renin release in patients with benign essential hypertension. Girculation $38: 353,1968$.

2) Hollenberg NK, Epstein M, Basch RI, et al : Renin secretion in essential and accelerated hypertension. Amer J Med 47 : 855, 1969.

3) Laragh JH, Baer L, Brunner HR, et al Renin, angiotensin and aldosterone system in pathogenesis and management of hypertensive vascular disease. Amer J Med 52 : 633, 1972.

4) Dunn MJ, Tannen RL: Low-renin hypertension. Kidney Intern. 5: 317, 1974.

5) Aurell M, Petterson M, Berglund G : Reninangiotensin System in essential hypertension. Lancet II : 342, 1975.

6) De Jong $\mathrm{W}$, Lovenberg $\mathrm{W}$, Sjoerdsma A : Increased plasma renin activity in the spontaneously hypertensive rat. Proc Soc Exp Biol Med 139: 1213, 1972.

7) Sen S, Smeby RR, Bumpus EM: Renin in rats with spontaneous hypertension. Circ Res 31 : 876, 1972.

8) Sinaiko A, Mirkin BL: Ontogenesis of the renin-angiotensin system in spontaneously hypertensive and normal wister rats. Circ Res 34 : 693, 1974.

9) Vincent M, Dupont J, Sassard J: Plasma renin activity as a function of age in two new strains of spontaneously hypertensive and normotensive rats Clin. Sci 50: 103, 1976. 
10) Kono $T$, Yoshimi $T$, Endo J: Determination of plasma renin activity using Dinabot Renin-Riakit. Jap Arch Intern Med 21 : 149, 1974.

11) Okamoto K, Aoki K: Development of a strain of spontaneously hypertensive rats. Jap Heart J 27 : 282, 1963.

12) Elser $\mathrm{MD}$, Julius $\mathrm{S}$, Randall $\mathrm{OS}$, et al: Relation of renin status to neurogenic vascular resistance in borderline hypertension. Amer J Cardiol 36 : 708, 1975.

13) Elser M, Julius S, Sweifler A, et al: Mild high-renin essential hypertension. Neurogenic human hypertension? New Eng J Med 296 : 405, 1977.

14) Sever PS, Birch M, Osikowaka B, et al: Plasma-noradrenaline in essential hypertension. Lancet I : 1078, 1977.
15) Mersereau WA, Moore S, Fernandez H: Renal renin in experimental nephrosclerosis. J Path 108 : 319, 1972.

16) Shiono $\mathrm{K}$, Sokabe $\mathrm{H}$ : Renin-angiotensin system in spontaneously hypertensive rats. Amer J Physiol 231: 1295, 1976.

17) Pederson EB, Kornerup HJ: Renal haemodynamics and plasma renin in patients with essential hypertension. Clin Sci 50 : 409, 1976.

18) Fukiyama K, Kumamoto K, Yamamoto $Y$, et al: Hypotensive response to angiotensin II analogue in benign essential hypertension. Jap Circul J 40 : 921, 1976.

19) Gordon DB: The renal basis of essential hypertension. Jap Heart J 15: 419, 1974.

20) Tobian L: Hypertension and the kidney. Arch Intern Med 133: 959, 1974. 